\title{
Applying multiple attribute decision-making methods to solve the problematic selection of living environment
}

\author{
Chien-Chien $\mathrm{Chu}^{1, \mathrm{a}^{*}}$, Ting-Yi Chiang ${ }^{1, \mathrm{~b}}$ and Yeng-Horng Perng ${ }^{1, \mathrm{c}}$ \\ ${ }^{1}$ Department of Architecture, National Taiwan University of Science and Technology, \\ No.43, Sec. 4, Keelung Rd., Da'an Dist., Taipei City 10607, Taiwan (R.O.C.) \\ aD10513013@mail.ntust.edu.tw, ${ }^{\text {bD}}$ 10313014@mail.ntust.edu.tw, ${ }^{c}$ perng@mail.ntust.edu.tw
}

\begin{abstract}
Keywords: Taiwan, Living Environment, Community welfare, Planning and Design, Building construction. Abstract. The selection of an ideal living environment is a complex process that involves multiple attributes, which makes the decision of an appropriate living environment difficult. Hence, a suitable assessment model is needed to solve the complexity. The multiple attribute decision-making methods-Fuzzy Delphi Method (FDM) and Analytical Hierarchy Process (AHP)-were the multiple attribute decision-making methods applied to determine the assessment criteria for the selection of living environment. By using FDM, the criteria for living the selection were determined. Subsequently, AHP was applied to ensure the consistency of each factor, that way an objective and accurate assessment tool for living area selection can be developed. The results show that the most significant factors are environments, followed by designs. Building constructions are less significant. Moreover, it was found in the study that community welfare is neglected. Therefore, it is suggested that (1) related authorities should strengthen community welfare and neighborhood development and that (2) social resources should be integrated in order to deliver social welfare and services to the community, allowing the people in the community to acquire the necessary resources and assistance.
\end{abstract}

\section{Introduction}

Due to changes in space, time, and environment, Taiwan's residential designs, policies, and regulations vary significantly in order to better adapt to the requirements in different periods. The notion of a living environment is one of people's basic necessities, and residential building is an important way to express people's way of living. The selection of an ideal living environment is a complex and multi-level decision-making process. The process basically involves external and internal factors; external factors include location, environment, and price while internal factors include residential building conditions, design quality, and building-construction quality [1-3].

Therefore, deciding an appropriate building environment for living is difficult, and hence, a suitable assessment model is needed. For this reason, the following specific research topics will be considered: summarizing the literatures in residential community environment; innovative green building design and building-construction work; applying Fuzzy Delphi Method (FDM) [4] and collecting recommendations from the experts to extract key factors that may affect the selection of living environment; performing assessment and screening for the determined factors on the basis of the results of previous studies such as [5-7]; applying Analytical Hierarchy Process (AHP) to decide the weighing and application order of each factor in each aspect [8]; and, finally, proposing relevant responding measures and suggestions.

\section{Research methods}

\section{Introduction of key factors}

After summarizing related papers and literatures, semi-structured questionnaires were designed as aids to properly conduct in-depth expert interviews. The purpose of in-depth expert interviews is to allow respondents to share their deeper understandings about the topics of concern; hence, an in-depth understanding is more important than a broad understanding [9]. Sometimes, the personal observations of certain respondents might be sufficient in representing hundreds of people's experiences $[10,11]$. To implement a quantitative analysis for decision-making behaviors, related literatures will be studied, and the factors that affecting the selection of living environments in 
Taiwan will be investigated. The Judgmental Sampling method was adopted in this study to perform an investigation on experts and scholars holding more than 10 years of experience in fields related to real estate. The experts in the industry include architects, real-estate appraisers, and/or managers with master's or $\mathrm{PhD}$ degrees. The experts from governmental agencies also have master's or $\mathrm{PhD}$ degrees. The experts in the academic field include professors and lecturers. All of them helped to complete the questionnaires and provided necessary information in order to acquire comprehensive and effective data. These data collected will be used to create comfortable new lives (environments 1-5), provide suitable living environments for modern people (designs 6-10), and improve the quality of residential buildings (building construction 11-16). The data acquired are organized and compiled into questionnaires with 16 factors (Table 1).

Table 1. Factors for assessment criteria items

\begin{tabular}{|c|c|c|}
\hline Project aspect & Related Factors & References \\
\hline \multirow{5}{*}{ environments } & 1. Cultural education facility (X1) & {$[12,13]$} \\
\hline & 2. Sport and leisure (X2) & [13] \\
\hline & 3. Living convenience facility (X3) & {$[12,13]$} \\
\hline & 4.Community welfare $(\mathrm{X} 4)$ & {$[13]$} \\
\hline & 5. Community awareness (X5) & {$[13]$} \\
\hline \multirow{5}{*}{ designs } & 6. Safety design (X6) & {$[14,15]$} \\
\hline & 7. Health design $(X 7)$ & {$[14,15]$} \\
\hline & 8. Convenience design (X8) & {$[14,15]$} \\
\hline & 9. Comfort design (X9) & {$[14,15]$} \\
\hline & 10. Sustainability design (X10) & {$[15]$} \\
\hline \multirow{6}{*}{$\begin{array}{l}\text { building } \\
\text { construction }\end{array}$} & 11. Foundation condition and terrain issue (X11) & {$[16]$} \\
\hline & 12. Good two-way communication (X12) & [17] \\
\hline & 13. Green construction materials (X13) & {$[18,19]$} \\
\hline & 14. Innovation technology (X14) & {$[20,21]$} \\
\hline & $\begin{array}{l}\text { 15. Change of material type and specification } \\
\text { during construction (X15) }\end{array}$ & {$[16]$} \\
\hline & 16. Schedule delay (X16) & {$[22,23]$} \\
\hline
\end{tabular}

\section{Fuzzy Delphi Method (FDM)}

FDM was applied for factor screening in order to remove factors with low discrimination index and to further simplify the questionnaires. The analysis results are shown in (Table 2), with expert consensus threshold value ( $\left.\mathrm{G}^{\mathrm{i}}\right)$ of 6.49 . There are 3 factors "X5, X12, X15" with value less than 6.49 , hence, they are removed, resulting in 13 factors left. 
Table 2. Fuzzy Delphi Method analysis result

\begin{tabular}{|c|c|c|c|c|c|c|c|}
\hline \multirow{2}{*}{ Factors } & \multicolumn{3}{|c|}{ Conservative value } & \multicolumn{3}{|c|}{ Optimistic value } & \multirow{2}{*}{$\mathbf{G}^{\mathbf{i}}$} \\
\hline & $\mathbf{C}_{\mathbf{L}}^{\mathbf{j}}$ & $\mathrm{C}_{\mathrm{U}}^{\mathbf{i}}$ & $\mathrm{C}_{\mathrm{M}}^{\mathrm{i}}$ & $\mathbf{O}_{\mathrm{L}}^{\mathbf{i}}$ & $\mathbf{O}_{\mathrm{L}}^{\mathbf{i}}$ & $\mathbf{o}_{\mathrm{M}}^{\mathbf{i}}$ & \\
\hline $\mathrm{X} 1$ & 4 & 7 & 5.24 & 6 & 10 & 8.2 & 6.56 \\
\hline $\mathrm{X} 2$ & 4 & 8 & 5.44 & 7 & 10 & 8.32 & 7.34 \\
\hline $\mathrm{X} 3$ & 4 & 8 & 5.36 & 7 & 10 & 8.32 & 7.33 \\
\hline $\mathrm{X} 4$ & 4 & 7 & 5.36 & 6 & 10 & 7.96 & 6.54 \\
\hline $\mathrm{X} 5$ & 3 & 6 & 4.52 & 6 & 9 & 7.6 & 6.00 \\
\hline X6 & 4 & 8 & 5.72 & 7 & 10 & 8.6 & 7.41 \\
\hline$X 7$ & 3 & 7 & 5.12 & 7 & 10 & 8.12 & 7.00 \\
\hline $\mathrm{X} 8$ & 3 & 7 & 5.2 & 6 & 10 & 8.52 & 6.58 \\
\hline $\mathrm{X} 9$ & 3 & 7 & 4.96 & 6 & 10 & 8.28 & 6.53 \\
\hline $\mathrm{X} 10$ & 3 & 7 & 5.2 & 6 & 10 & 8.32 & 6.56 \\
\hline $\mathrm{X} 11$ & 4 & 7 & 5.44 & 6 & 10 & 8.08 & 6.57 \\
\hline $\mathrm{X} 12$ & 3 & 7 & 5.12 & 6 & 9 & 7.44 & 6.43 \\
\hline X13 & 4 & 7 & 5.2 & 6 & 10 & 8.28 & 6.56 \\
\hline X14 & 3 & 7 & 5.32 & 6 & 10 & 8.28 & 6.58 \\
\hline X15 & 3 & 7 & 4.88 & 6 & 9 & 7.08 & 6.34 \\
\hline X16 & 4 & 7 & 5.28 & 6 & 10 & 7.96 & 6.53 \\
\hline
\end{tabular}

\section{Results verification and analysis}

\section{Introduction of AHP framework and expert questionnaires}

According to the previous section, the first stage is to screen out 13 key factors by using FDM. In the second stage, AHP expert questionnaire investigation will be carried out.

At this stage, experts and researchers are still the objects of investigation. Besides establishing the hierarchal framework for the selection of living environment in Taiwan, it is also essential to understand the correlation between each influential factors in order to acquire the relative weighing between factors of different levels as well as the overall weighing, both of which will be used for planning subsequent supporting measures. Based on the investigation results, the order and weighing distribution of factors were determined to reduce the hypothesis value, allowing the decision making to be more objective and appropriate in matching the actual demand.

\section{Sample statistics and AHP questionnaire analysis}

In this study, a total of 25 questionnaires were sent out, with a recovery rate of $100 \%$.

After performing AHP analysis (Table 3), the top 3 factors that concerned the most by the experts and the scholars are safety design (X6), sport and leisure (X2) and living convenience facility (X3). Factor X6 is the improvement of user's life quality, encouraging user-friendly spatial design. This factor takes the protection of life and the safeguard of asset as the core value and puts emphasis on the design that fulfils user-friendly and everyday-life needs, providing a safe living environment for the user. Furthermore, X2 and X3 are also important factors that will impact the selection of living environment. 
Table 3. Relative weighing of major criteria and minor criteria

\begin{tabular}{|c|c|c|c|c|c|}
\hline Criteria & Level (1) Wi & Sub-Criteria & Level (2) Wi & Overall Wi & $\begin{array}{c}\text { Overall } \\
\text { Sequence }\end{array}$ \\
\hline \multirow{4}{*}{ environments } & \multirow{4}{*}{38.92} & $\mathrm{X} 1$ & 28.90 & 9.63 & 5 \\
\hline & & $\mathrm{X} 2$ & 31.61 & 10.54 & 2 \\
\hline & & $\mathrm{X} 3$ & 30.02 & 10.01 & 3 \\
\hline & & $\mathrm{X} 4$ & 9.47 & 3.16 & 13 \\
\hline \multirow{5}{*}{ designs } & \multirow{5}{*}{32.50} & X6 & 35.22 & 11.74 & 1 \\
\hline & & $\mathrm{X} 7$ & 26.33 & 8.78 & 7 \\
\hline & & $\mathrm{X} 8$ & 16.27 & 5.42 & 10 \\
\hline & & X9 & 11.98 & 3.99 & 11 \\
\hline & & $\mathrm{X} 10$ & 10.20 & 3.40 & 12 \\
\hline \multirow{4}{*}{$\begin{array}{l}\text { building } \\
\text { construction }\end{array}$} & \multirow{4}{*}{28.58} & $\mathrm{X} 11$ & 20.54 & 6.85 & 9 \\
\hline & & $\mathrm{X} 13$ & 23.47 & 7.82 & 8 \\
\hline & & $\mathrm{X} 14$ & 29.49 & 9.83 & 4 \\
\hline & & $\mathrm{X} 16$ & 26.50 & 8.83 & 6 \\
\hline
\end{tabular}

\section{Supporting measures and discussions}

It is noted from Table 3 (Relative weighing of major criteria and minor criteria) that community welfare (X4), sustainability design (X10) and comfort design (X9) are the 3 factors that need to be improved first. For this reason, supporting measures were suggested as described below:

\section{Community welfare $(3.16 \%)$}

The assessment method and definition include elderly caring system, community babysitting system and kindergarten. Currently, the investment in infrastructure and social welfare are far from expectation, making a big urban-rural gap in terms of transportation, education, leisure, entertainment and community convenience. Therefore, besides community management, an ideal community also needs to establish community welfare facility and institution, bringing government policies into the community in order to achieve the goal of local resources sharing and continuity. Details are described as follows:

I The low birth rate problem in Taiwan is more serious than that in other countries, hence, better babysitting system should be established.

I Implement "Long-Term Caring Service Center", "Long-Term Caring Information System" and "Long-Term Caring Service Act" and work in coordination with National Health Insurance to improve long-term caring services.

I It is essential to strengthen elderly caring system, community babysitting system and kindergartens since they will have a definite impact on community welfare.

\section{Sustainability design ( $3.40 \%$ )}

"Energy Saving Performance" and "Energy Management" were taking into account when evaluating construction building's facilities or equipment systems. For instance, the air conditioning system, lighting system, and power system installed in each type of buildings will be evaluated based on their power efficiency. Furthermore, buildings will also be evaluated on whether or not they have installed energy-saving or renewable energy equipment and whether or not they have energy management capabilities. Measures on how to reduce the power consumption of building equipment are described as follows: 
I Promote the idea of energy saving via the implementation of environmental education programs in order to build correct energy-saving knowledge and avoid wasting Earth's resources.

I Government should list "Energy Saving Performance" and "Energy Management" as key policies.

I Government should encourage companies to implement energy-saving items and use energy-saving products by offering subsidies.

\section{Comfort design ( $3.99 \%$ )}

Different designs are implemented to achieve the goal of physical and mental relaxation. The spatial comfort requirement demanded by the user will be assessed. Details are described as follows:

I By considering the risks of various factors (such as PM2.5 air pollution, water pollution, soil contamination and indoor renovation), more innovative green building design concept, methods as well as prevention equipment are needed in order to achieve a comfort and healthy living environment.

I The implementation of ventilation path and new construction designs can help to increase the proportion of green plants and reduce man-made surface work. The formation of natural micro climate and ventilation (i.e., by considering the opening diameter, height ratio and wind path during building design) can reduce the power consumption of air conditioning system, improving living quality.

I Double-layer roof can be installed to reduce the heat transfer through the roof (air gap within the roof reduces heat transfer). Moreover, roof ventilation system can be installed to reduce the heat loading inside the building.

\section{Conclusion and future study}

To create an appropriate living space and select an ideal living environment, public areas within communities and the surrounding neighborhoods were studied, and the problem of living-environment selection was investigated. In this study, FDM and AHP were applied to analyze the model for living-environment selection, with the hope that a suitable living environment can be created with limited resources. It is suggested that governments should strengthen community welfare and enhance neighborhood development by better incorporating social resources in order to bring social welfare services (such as babysitting services, elderly care services, and community welfare service centers) to communities, which would bring the resources and assistance required by communities. Furthermore, the elderly care system should also be improved, as it will be the key item of development for Taiwan's future society. Experts believe that AHP is one of the best analysis tools for evaluating the selection of a living environment. AHP can be supported by comprehensive academic theories as well as the results generated can benefit people in understanding the overall status of a living environment. Moreover, the method can be used by governmental agencies and private companies to improve under-performance items and can also serve as a good reference for the general public in assessing their own living environments.

\section{References}

[1] C. C. Caroline, Designing the customer experience, Building Research and Information. 31 (5) (2003) 357-366.

[2] I. Dikmen, M. T. Birgonul, \& S. Kiziltas, Strategic use of quality function deployment (QFD) in the construction industry, Building and Environment. 40 (2005) 245-255.

[3] Y. K. Juan, S. G. Shih, \& Y. H. Perng, Decision support for housing customization: A hybrid approach using case-based reasoning and genetic algorithm, Expert Systems with Applications. 31(1) (2006) 83-93.

[4] T. J. Murray, L. L. Pipino, \& J. P. van Gigch, A pilot study of fuzzy set modification of Delphi, Human Systems Management. 5(1) (1985) 76-80. 
[5] A. Ishikawa, A. Gakuin, M. Amagasa, T. Shiga, G. Tomizawa, H. Mieno, \& R. Tatsuta, The max-min Delphi method and fuzzy Delphi method via fuzzy integration, Fuzzy Sets and Systems. 55(3) (1993) 241-253.

[6] A. Kaufmann, \& M. M. Gupta, Fuzzy Mathematical Models in Engineering and Management Science, New York, North-Holland, 1988.

[7] Y. F. Kuo, \& P. C. Chen, Constructing performance appraisal indicators for mobility of the service industries using Fuzzy Delphi Method, Expert Systems with Applications. 35(4) (2008) 1930-1939.

[8] T. L. Saaty, The Analytical Hierarchy Process: Planning, Priority Setting. Resource Allocation. New York: McGraw-Hill Book Co, 1980.

[9] H. J. Rubin, I. S. Rubin, Qualitative interviewing: The art of hearing data. Thousand Oaks, CA: Sage, 2011.

[10]R. S. Weiss, Learning from strangers: The art and method of qualitative interview studies. Simon and Schuster, 1994.

[11]T. Y. Chiang, Y. H. Perng, \& L. E. Liou, Impact and Adaptation Strategies in Response to Climate Change on Taiwan's Water Resources, Applied Mechanics \& Materials. 858 (2017) 335-341.

[12]B. C. Arimah, An empirical analysis of the demand for housing attributes in a third world city. Land Economics. 68(4) (1992) 366-379.

[13] Ministry of the Interior, Taiwan, EEWH-NC (Evaluation Manual for Green Building in Taiwan), Architecture and Building Research Institute, 2015.

[14] WHO (World Health Organization), Expert Committee on the Public Health Aspects of Housing. First Report. Geneva, 19-26 June, 1961.

[15]C. J. Yang, \& S. D. Chang, The Study of Diagnosis Model for the Sustainable Urban Residential Area. Urban Studies. 15(6) (2008) 43-48.

[16]D. S. Santoso, \& S. Soeng, Analyzing Delays of Road Construction Projects in Cambodia: Causes and Effects, Journal of Management in Engineering. 32(6) (2016) 05016020.

[17]P. A. Dabholkar, D. I. Thorpe, \& J. O. Rentz, A measure of service quality for retail stores: scale development and validation, Journal of the Academy of marketing Science. 24(1) (1995) 3-16.

[18]R. Pearce, J. R. DuBose, \& S. J. Bosch, Green building policy options for the public sector, Journal of Green Building. 2(1) (2007) 156-174.

[19]R. J. Yang, P. X. W. Zou, \& J. Wang, Modelling stakeholder-associated risk networks in green building projects, International journal of project management. 34(1) (2016) 66-81.

[20]P. T. Lam, E. H. Chan, C. S. Poon, C. K. Chau, \& K. P. Chun, Factors affecting the implementation of green specifications in construction, Journal of environmental management. 91(3) (2010) 654-661.

[21] G. Y. Qi, L. Y. Shen, S. X. Zeng, \& O. J. Jorge, The drivers for contractors' green innovation: an industry perspective, Journal of Cleaner Production. 18(14) (2010) 1358-1365.

[22] Y. Q. Chen, J. Y. Liu, B. G. Li, \& B. S. Lin, Project delivery system selection of construction projects in China, Expert Systems with Applications. 38(5) (2011) 5456-5462.

[23] J. K. Larsen, G. Q. Shen, S. M. Lindhard, \& T. D. Brunoe, Factors affecting schedule delay, cost overrun, and quality level in public construction projects, Journal of Management in Engineering. 32(1) (2015) 04015032. 